\title{
Leaf trapping and retention of particles by holm oak and other common tree species in Mediterranean urban environments
}

Article

Accepted Version

Blanusa, T., Fantozzi, F., Monaci, F. and Bargagli, R. (2015) Leaf trapping and retention of particles by holm oak and other common tree species in Mediterranean urban environments. Urban Forestry \& Urban Greening, 14 (4). pp. 1095-1101. ISSN 1618-8667 doi:

https://doi.org/10.1016/j.ufug.2015.10.004 Available at https://centaur.reading.ac.uk/45760/

It is advisable to refer to the publisher's version if you intend to cite from the work. See Guidance on citing.

Published version at: http://www.sciencedirect.com/science/article/pii/S1618866715001405

To link to this article DOI: http://dx.doi.org/10.1016/j.ufug.2015.10.004

Publisher: Elsevier

All outputs in CentAUR are protected by Intellectual Property Rights law, including copyright law. Copyright and IPR is retained by the creators or other copyright holders. Terms and conditions for use of this material are defined in the End User Agreement. 


\section{CentAUR}

Central Archive at the University of Reading

Reading's research outputs online 
$1 \quad$ Leaf trapping and retention of particles by holm oak and other common tree species

2

3

4 5

7

8

9

10

\section{in Mediterranean urban environments}

Tijana Blanusa ${ }^{a, b, *}$, Federica Fantozzi $^{\mathrm{c}}$, Fabrizio Monacic $^{\mathrm{c}}$, Roberto Bargaglic

\author{
aPlant Sciences Department, Royal Horticultural Society, Wisley, Woking GU23 6QB, \\ UK, UK \\ ${ }^{\mathrm{b}}$ School of Agriculture, Policy and Development, University of Reading, Reading, RG6 \\ 6AR \\ 0 'Department of Physical, Earth and Environmental Sciences, University of Siena, Via \\ 1 P.A. Mattioli, 4, Siena 53100, Italy \\ 3 *Corresponding author, Tel.:+44 1183786628 \\ E-mail address: tijanablanusa@rhs.org.uk
}

12 


\section{Abstract}

17

18 Holm oak (Quercus ilex), a widespread urban street tree in the Mediterranean region, is widely used as biomonitor of persistent atmospheric pollutants, especially particulate-bound metals.

20 By using lab- and field-based experimental approaches, we compared the leaf-level capacity 21 for particles' capture and retention between $Q$. ilex and other common Mediterranean urban 22 trees: Quercus cerris, Platanus $\times$ hispanica, Tilia cordata and Olea europaea. All applied 23 methods were effective in quantifying particulate capture and retention, although not univocal 24 in ranking species performances. Distinctive morphological features of leaves led to differences in species' ability to trap and retain particles of different size classes and to accumulate metals after exposure to traffic in an urban street. Overall, P. xhispanica and T. cordata showed the largest capture potential per unit leaf area for most model particles $\left(\mathrm{Na}^{+}\right.$ and powder particles), and street-level $\mathrm{Cu}$ and $\mathrm{Pb}$, while $Q$. ilex acted intermediatelly. After wash-off experiments, $P . \times$ hispanica leaves had the greatest retention capacity among the tested species and O. europaea the lowest. We concluded that the Platanus planting could be considered in Mediterranean urban environments due to its efficiency in accumulating and retaining airborne particulates; however, with atmospheric pollution being typically higher in winter, the evergreen $Q$. ilex represents a better year-round choice to mitigate the impact of airborne particulate pollutants.

Keywords: airborne particles, metals, leaf capture, Quercus cerris, Quercus ilex, Platanus 


\section{$41 \quad$ Highlights}

42 43

- London plane and lime tree leaves captured most $\mathrm{Na}^{+}$aerosol and powder particles per unit leaf area.

45

- London plane leaves showed the largest metals' $(\mathrm{Pb}, \mathrm{Zn}, \mathrm{Cu})$ capture potential, near an urban street.

- London plane leaves also showed greatest capacity for particle retention after wash off.

- In a year-round scenario, Holm oak likely has the highest potential for PM removal due

49 


\section{INTRODUCTION}

52

Urban population is increasing worldwide and a further rise in urbanisation is predicted (Buhaug and Urdal, 2013). One of the main implications of urbanization is air pollution which is associated with several health outcomes for urban residents, including respiratory and cardiovascular illness, neurological disorders and cancers (e.g. Pope and Dockery, 2006; HEI, 2010). In many urban environments the airborne particulate matter (PM) affects more people than any other atmospheric pollutant and no threshold PM concentration has been identified below which no damage to health is observed (WHO, 2014). It has been estimated that PM causes 3.7 million premature deaths annually worldwide and more than 450,000 in Europe (WHO, 2014). Particulate matter from natural (sea salt, soil dust, volcanic ash, forest fires, pollen) or anthropogenic sources (fuel combustion in thermal power generation, traffic, incineration and domestic heating for households) is directly emitted to the atmosphere (primary) or is formed in air as secondary inorganic or organic aerosols from precursor gases such as $\mathrm{SO}_{2}, \mathrm{NO}_{x}, \mathrm{NH}_{3}$, and volatile organic compounds. Therefore, the urban PM is a complex mixture of different phases, with different chemical composition and size. Particles with an aerodynamic diameter $<10 \mu \mathrm{m}\left(\mathrm{PM}_{10}\right)$ can enter the human airways, particles $<2.5 \mu \mathrm{m}\left(\mathrm{PM}_{2.5}\right)$ can reach pulmonary air sacs (Baeza-Squiban et al., 1999) and those $<0.1 \mu \mathrm{m}$ enter the blood circulation system (EEA, 2014).

In cities, the traffic and especially diesel-fuelled vehicles are an important source -close to the ground - of PM-bearing metals and particulate-bound polyaromatic hydrocarbons which have been linked with adverse health effects (e.g. HEI, 2010). Non-exhaust emissions (tyre, brake and road surface wear, corrosion and dust re-suspension) from road traffic are about 50 $\%$ of exhaust emissions of primary $\mathrm{PM}_{10}$ and about $22 \%$ of the exhaust emissions of primary $\mathrm{PM}_{2.5}$ (Hak et al., 2009). Therefore, even with zero tailpipe emissions, the traffic will continue to be a very important source of PM in urban environments (Kumar et al., 2013).

Particles can be removed from the atmosphere by various deposition mechanisms (NEGTAP, 2001), with dry deposition being the main pathway, especially in areas with scarce atmospheric precipitation such as the Mediterranean region. Vegetation has a pivotal role in the removal of the atmospheric particulate in terrestrial ecosystems. Dry deposition processes and the particle interception by trees are affected by many factors such the canopy characteristics, wind speed, temperature, particle size, gas solubility as well as leaf pubescence, size and morphology (Beckett et al., 2000; Freer-Smith et al., 2005; Hofman et al., 2014; Weber et al., 2014). Most particles adsorbed on leaves and other plant surfaces are often re-suspended to the atmosphere, 
washed off by rain, or dropped to the ground with leaf and twig fall. Although it is well-known that the temporary retention of particles by urban trees can reduce atmospheric PM concentrations (e.g. Beckett et al., 2000, Fowler et al., 2004; Novak et al., 2006) the effectiveness of street trees or vertical gardens as a long-term alternative to other measures such as the wet cleaning of streets is still debated (Litschke and Kuttler, 2008). Some previous quantitative estimates of $\mathrm{PM}_{10}$ reduction by urban vegetation on the city-scale suggested a small effect (often < 1\%; e.g. Novak et al., 2006; Escobedo and Nowak, 2009; Tallis et al., 2011). However, as discussed by Litschke and Kuttler (2008), these estimates assumed a particle deposition velocity (i.e. the quotient of the particles' flow rate towards the leaf surface and the atmospheric particle concentration) of about $1 \mathrm{~cm} \mathrm{~s}^{-1}$, whereas in-situ measurements indicate considerably higher values and literature data for $\mathrm{PM}_{10}$ deposition velocities to vegetation vary from $\sim 0.01$ to $\sim 10 \mathrm{~cm} \mathrm{~s}^{-1}$. This variability is due to particle characteristics, meteorological conditions as well as to tree species differences in canopy architecture, leaf morphology and surface properties (Pugh et al., 2012; Maher et al., 2013).

Modelling, as well as a number of experimental field and laboratory approaches, have been used to evaluate the PM interception by leaves from a number of plant species (e.g. Beckett et al., 2000; Sæbø et al., 2012; Räsänen et al., 2013). It is known that leaf morphology and wettability play an important role in the interception of airborne particles and in their resuspension to the atmosphere (e.g. McPherson et al., 1994). However, limited information is available about the wash-off by rain of adsorbed particles from leaves of different tree species (Neinhuis and Barthlott, 1998).

In order to contribute to the selection and maintenance of tree species with a higher deposition velocity for an efficient PM interception in Italian cities we compared the particle capture and retention capacity by leaves from a popular and prevalent tree species in Italian urban and roadside environments - Quercus ilex L., to that of possible alternatives: Quercus cerris L., Platanus ×hispanica Münch., Tilia cordata Mill., and Olea europaea L. In Mediterranean regions, the evergreen holm oak $(Q$. ilex) has a wide natural distribution and in Italy it has been used since the sixteenth century in the landscaping of urban and rural parks and gardens. Holm oak has a large canopy, as wells as Leaf Area Index (LAI) typically higher than that of other broad-leaf species (Sgrigna et al., 2015); its leaves have a hair cover and thick waxy cuticles. Because of these leaf properties, which enhance the scavenging and retention of airborne particles and the incorporation of lipophilic organic contaminants, holm oak leaves were widely used for biomonitoring persistent pollutants in many Italian urban areas (e.g. Monaci et al., 2000; Gratani et al., 2008; Fantozzi et al., 2013; Ugolini et al., 2014). Through 
119 a quantitative analysis of PM fractions on $Q$. ilex leaves collected (three times in a year) in an 120 urban environment, Sgrigna et al. (2015) found a mean surface PM deposition of $20.6 \mu \mathrm{g} \mathrm{cm}^{-}$

$1212^{2}$, a value in the same range of that reported for other urban tree species by Dzierżanowski et 122 al. (2011). Having in mind the need to diversify planting in order to increase the resilience of 123 urban trees and decrease susceptibility to pests and diseases (Laćan and McBride, 2008), in our 124 study the leaf particle interception and retention by $Q$. ilex were compared with those of other 125 urban tree species to identify possible alternative/complementary trees as PM mitigating tools in Mediterranean urban environments. To evaluate if a cheap and accessible method can produce reliable estimates of tree leaf potential for $\mathrm{PM}$ interception, $\mathrm{NaCl}$ aerosol and talcum powder were blown onto the leaves in a simple wind tunnel. The results of these laboratory experiments were compared with those from metal particle accumulation in leaves exposed to traffic in an urban street. We chose three metals $(\mathrm{Pb}, \mathrm{Cu}$ and $\mathrm{Zn})$ routinely associated with anthropogenic pollution sources (Espinosa et al., 2002, Wang 2006) as indicators of street-level pollution; their concentrations are reported in numerous studies (e.g. Davis et al., 2001, Lindgren, 1996), so this should enable baseline comparisons. The leaf particle retention capability in the five tree species was also evaluated by simulating a rainfall. Thus, this work attempted to evaluate the agreement among different laboratory experiments and to compare the behavior of leaves from five selected tree species in terms of particle capture and retention, in the laboratory and the field.

\section{MATERIALS AND METHODS}

\subsection{Plant material}

The main leaf characteristics of the five tree species common in Mediterranean urban areas are summarized in Table 1. Platanus $\times$ hispanica (London plane) has relatively large, stiff leaves coated with fine, firm hairs (during springtime); those of $T$. cordata (lime tree) are also large but mostly hairless, except for small tufts of hair in the leaf vein axils (Hölscher, 2003). Both $Q$. ilex (holm oak) and Q. cerris (Turkey oak) leaves have a water-repellent surface mainly due to the thick epicuticular waxy layer. Quercus ilex is also characterized by stellate trichomes on the surface (Quero et al., 2006). Olea europea (olive) has small silvery-green leaves with glossy and veined upper surface (Marchi et al., 2008).

In all experiments, young fully-expanded leaves of the current year's growth were used.

150 Wind-tunnel and laboratory experiments were carried out in Summer 2012 at the University of

151 Reading (UK) (see section 2.2) and leaves were collected from the 3-year-old trees maintained 152 in ventilated glasshouses (O. europaea, $P$. ×hispanica and $Q$. ilex), or from nearby field-grown 
mature trees ( $Q$. cerris and T. cordata); leaves from 2-year-old sections of the branches were used in all experiments. During the Summer 2013, short branches (from 2-year-old wood), of all tree species were excised from mature trees from the Siena Botanical Garden and were exposed to traffic in an urban street (see section 2.3).

\subsection{Laboratory wind tunnel experiments}

\subsubsection{Method development}

The wind tunnel used in the experiments to distribute the particles to the leaves was an open-circuit type (Figure 1), $50 \mathrm{~cm}$ long and $15 \mathrm{~cm}$ in diameter. Particles were generated from a $0.1 \mathrm{M} \mathrm{NaCl}$ solution with a pressure sprayer (nozzle outlet diameter $=1 \mathrm{~mm}$ ) or by a powderdispenser sieve containing fine powder (Johnson's powder, Johnson \& Johnson, New Jersey, USA). Particles were dispensed in front of a splash-proof DC fan (IP54 Ebm-papst, Bachmühle, Germany) at the entry point to the wind tunnel. Droplet diameters and powder particle size were in the range from $0.05 \mu \mathrm{m}$ to $15 \mu \mathrm{m}$.

Preliminary experiments were performed with Petri plates, glass slides and artificial leaves held by a custom made rigid mesh support, to establish optimal experimental conditions (i.e. length of application time, amount of $\mathrm{NaCl}$ solution and powder, and the distance between leaves and the fan). Artificial leaves were constructed to mimic the average shape and size of the five different tree species, tracing on paper three real leaves with a shape/size representing the average for every species and then laminating them. Variations in weight of Petri plates, slides and artificial leaves (before and after particle application; 10 replicates for each treatment) were determined with a precision balance. Preliminary tests using $30 \mathrm{ml} \mathrm{NaCl}$ solution or $5 \mathrm{~g}$ of powder, at a distance of $20 \mathrm{~cm}$, with an exposure time of $5 \mathrm{~s}$, and wind/air speed in the tunnel of $6.75 \mathrm{~m} \mathrm{~s}^{-1}$ gave the most reproducible results.

For the experiments, fresh leaves of the five tree species were then inserted into a mesh support (Figure 2) before exposing them to various treatments.

\subsubsection{Capture and retention of $\mathrm{NaCl}$ aerosol}

181 The fresh weight and the leaf area (LA) of 40 leaves of each tree species were measured before mounting leaves in a support and placing them into the wind tunnel for the exposure to $\mathrm{NaCl}$ aerosol. Additional three leaves per species (sprayed only with distilled water) represented controls. After aerosol exposure, all leaves were carefully laid out to air dry under a laminar extractor fan and then 20 leaves were oven-dried for $24 \mathrm{~h}$ at $70{ }^{\circ} \mathrm{C}$. Dry leaf samples were pooled in groups of 2-3 leaves to produce 6-9 replicates per species; leaves were manually 
ground and homogenized using a mortar and pestle. About $500 \mathrm{mg}$ of each sample were digested with concentrated $\mathrm{HNO}_{3}$ at $120{ }^{\circ} \mathrm{C}$ for $8 \mathrm{~h}$ in a microwave pressurized digestion system. The mineralized samples of exposed and control leaves were analyzed with an atomic absorption spectrophotometer (AAS) and $\mathrm{Na}$ concentrations (expressed in $\mu \mathrm{g} \mathrm{g}^{-1} \mathrm{~d}$.w. basis) were determined by the method of standard additions. Procedural blanks were below the $\mathrm{Na}$ detection limit; the accuracy of digestion and analytical procedures was checked by routine determination of Na concentrations in standard reference materials (SRM No 2711a and 1515) from the National Institute of Standards and Technology (Gaithersburg, USA). The analytical recoveries from the certified values ranged from 86 to $97 \%$.

The other 20 treated leaves and control leaves were inserted again into the wind tunnel and exposed to distilled water aerosol for $5 \mathrm{~s}$ at a distance of $20 \mathrm{~cm}$ from the fan; leaves were positioned perpendicularly to the air flow. Wash-off solution was collected in a Petri plate and analyzed for $\mathrm{Na}^{+}$concentrations with the AAS.

The leaf $\mathrm{NaCl}$ aerosol capture capacity was estimated by analysing leaf $\mathrm{Na}^{+}$concentrations in two ways. One was by simply subtracting leaf $\mathrm{Na}^{+}$concentrations before and after the experiment ('N'). This was done to assess the total $\mathrm{Na}^{+}$captured by each leaf, not taking into the account differences in leaf size.

Other was by accounting for the leaf weight and leaf area so that a $\mathrm{Na}^{+}$capture potential $(\mathrm{Cp})$ 'per unit' of leaf weight and leaf area (LA) of different species can be compared. To do this the following equation was used:

$$
\mathrm{Cp}=\mathrm{N} \times(\text { leaf weight/LA) }
$$

where ' $\mathrm{N}$ ' was the difference in leaf $\mathrm{Na}^{+}$concentration before and after the experiment (expressed in $\mathrm{mg} \mathrm{g}^{-1}$ ) and ' $\mathrm{D}$ ' was the leaf 'density' (obtained as a ratio of leaf weight and leaf area).

211 The $\mathrm{Na}^{+}$wash-off $(\mathrm{R})$ was calculated using the equation:

$$
\mathrm{R}=\mathrm{N}_{\mathrm{r}} / \mathrm{LA}
$$

where ' $\mathrm{N}_{\mathrm{r}}$ ' was the $\mathrm{Na}^{+}$concentration in the runoff $\left(\mathrm{mg} \mathrm{l}^{-1}\right)$ and LA was leaf area from which runoff was collected.

\subsubsection{Capture and retention of powder particulate}

217 A further 40 leaves of each species, whose leaf area and fresh weight were previously 218 determined, were exposed to $5 \mathrm{~g}$ of powder at $20 \mathrm{~cm}$ from the fan. Leaves were then carefully

219 laid down in order to avoid loss of powder; a piece of leaf tissue $\left(1 \mathrm{~cm}^{2}\right)$ was cut from the centre of the lamina of 20 leaves and fixed onto a microscope slide. Powder particle retention 
of the adaxial leaf surface (facing the fan) was determined by counting the number of particles using a digital image-analysis system connected to a light microscope. For each tree species, the number of particles on 20 treated leaves was counted in four random squares of $1 \mu \mathrm{m}^{2}$ area per leaf and results were reported as particle number $\mathrm{mm}^{-2}$. Two untreated leaves acting as controls were also analyzed using the same procedure.

The other 20 treated leaves were inserted again into the wind tunnel, exposed to distilled water aerosol as detailed above and then analyzed by light microscope to assess the powder retention after wash-off.

\subsection{Field experiment}

231 Three branches with similar length and leaf age were excised from each of the Q. ilex, Q. cerris, P. ×hispanica, T. cordata and O. europaea trees in the Botanical Garden of Siena (a green park with no adjacent traffic or other sources of airborne metals), and carefully washed with distilled water. Three subsamples of leaves from each tree species were analyzed for $\mathrm{Cu}, \mathrm{Zn}$ and $\mathrm{Pb}$ concentrations to assess the metal concentrations before the exposure (for details on samples preparation, chemical digestion and analytical determination see Fantozzi et al., 2013). On 2 July 2013 the branches, inserted in $10 \mathrm{ml}$ plastic flasks with water, which was changed every two days, were randomly placed on the $10 \mathrm{~m}$ long stretch of a wall $(2 \mathrm{~m}$ above the ground and $1 \mathrm{~m}$ away from a street in Siena city centre, with 200-1500 vehicles $\mathrm{h}^{-1}$ (ARPAT, 2011) (Figure 3). During the 21 days exposure there was no atmospheric precipitation. All exposed leaves on each branch were pooled and the 3 composite samples for each tree species were analyzed for total $\mathrm{Cu}, \mathrm{Zn}$ and $\mathrm{Pb}$ concentrations.

\subsection{Data analysis}

245 Data were analyzed using GenStat (11 ${ }^{\text {th }}$ Edition, Lawes Agricultural Trust, Rothamsted 246 Experimental Station, UK). Analysis of variance (ANOVA) was used to assess the effects of the plant species on measured parameters; variance levels were checked for homogeneity and values were presented as means with associated least significant differences (LSD, $P=0.05$ ) or standard error (SE).

\section{RESULTS}

\subsection{Laboratory wind-tunnel experiments}


255 Table 2. shows $\mathrm{NaCl}$ aerosol capture potential (Cp) by the different tree leaves. Larger leaves like $P$. $\times$ hispanica and $T$. cordata captured more $\mathrm{Na}^{+}$than smaller leaves (e.g. $1.97 \mathrm{mg} \mathrm{g}^{-1}$ vs $0.36 \mathrm{mg} \mathrm{g}^{-1}$ for Tilia compared to Olea, respectively); Tilia was additionally most efficient in $\mathrm{Na}^{+}$capture per unit leaf area $\left(0.015 \mathrm{mg} \mathrm{cm}^{-2}\right)$, followed by $Q$. cerris and $P$. $\times$ hispanica $(0.009$ and $0.008 \mathrm{mg} \mathrm{cm}^{-2}$ ). P. ×hispanica and T. cordata leaves also showed significantly less ( $\mathrm{p}<$ $0.01)^{~} \mathrm{Na}^{+}$wash-off (Table 2). The $\mathrm{Na}^{+}$wash-off was most pronounced in O. europaea and intermediate in $Q$. ilex and $Q$. cerris $(1.87,0.55$ and 0.53 , respectively, Table 2$)$.

\subsubsection{Capture and retention of powder particulate}

Table 3 summarizes the results of the powdering experiment with talcum and the following wash-off treatment. Tilia cordata and O. europaea leaves captured the greatest number of powder particles; all species, except $Q$. cerris, captured mostly particles in the 5-10 $\mu \mathrm{m}$ range (Table 3). Leaves from the two oak species showed a lower capture efficiency for the smaller particles $(<5 \mu \mathrm{m})$ and a significantly higher $(\mathrm{p}<0.01)$ capture efficiency for coarser particles $(>10 \mu \mathrm{m})$ than the other three species. The wash-off treatment removed less than $10 \%$ of the total number of particles adsorbed on $P$. xhispanica leaves and about 31, 48, and $64 \%$ of those adsorbed on $Q$. ilex, T. cordata, and $Q$. cerris, respectively. However, under the adopted experimental conditions, about $60 \%$ of the finest particles $(<5 \mu \mathrm{m})$ were retained by Q. ilex leaves and about $42 \%$ in those of London plane, lime tree and Turkey oak. The olive leaves showed a minimal capacity to retain adsorbed particles (only <13\%) (Table 3).

275

\subsection{Field experiment}

277 Average concentrations $(\mu \mathrm{g} / \mathrm{g}$ ) of $\mathrm{Cu}, \mathrm{Pb}$ and $\mathrm{Zn}$ in the leaves exposed for 21 days to the street278 level polution in Siena varied between the plant species, and between the metals (Table 4). 279 Lead $(\mathrm{Pb})$ concentrations were no higher than $0.40 \mu \mathrm{g} \mathrm{g}^{-1}$, but $\mathrm{Cu}$ and $\mathrm{Zn}$ up to $13-16 \mu \mathrm{g} \mathrm{g}^{-1}$ 280 after 3 weeks of exposure to streel-level traffic in dry summer weather. In terms of leaf-level capture, for $\mathrm{Pb}$ for example, concentration increase after exposure ranged from $5.8 \%$ in $O$. europea to $27.9 \%$ in $P$. xhispanica. For other metals, this range of increase in metal concentration between different species was smaller: e.g. for $\mathrm{Cu}$ it was between $12.9 \%(O$. europea) to $26.6 \%$ (P. xhispanica) and even smaller for Zn $(9.20 \%$ in $Q$. ilex to $15.4 \%$ for $P$. $\times$ hispanica). $P . \times$ hispanica showed a greatest increase in concentrations of metals after the exposure compared to other species. Tilia and $Q$. ilex were comparable in terms of 
concentration increase for $\mathrm{Zn}: 9-10 \%$ for leaf $\mathrm{Cu}$ concentration increase after street-level exposure (Table 4).

\section{DISCUSSION}

292 Previous studies indicate that PM interception by trees is often (although not exclusively, see

293 Hofman et al., 2014) affected by canopy architecture; thus conifers, in spite of the low unit 294 needle-leaf area, usually show the highest capture efficiency (e.g. Beckett et al., 2000; FreerSmith et al., 2004; Hwang et al., 2011; Räsänen et al., 2013). All the species considered in this study had leaves capable to distinctively collect airborne particulate; however, the spatial structure of branches and twigs of different species and the lack of foliage during the winter in chosen deciduous species would decrease their capacity for PM trapping on a year-round basis. The administration of $\mathrm{NaCl}$ aerosol, with an approach previously used by Beckett et al. (2000) and Räsänen et al. (2013), suggested a much higher capture potential (Cp) and a much lower $\mathrm{Na}^{+}$wash-off in Tilia and P. ×hispanica leaves than in the other species (Table 2). The leaf wettability affects the capture of aerosols (Freer-Smith et al., 2004) and some features of $Q$. ilex, Q. cerris and O. europaea leaves such as their sclerophylly, superficial roughness, presence of trichomes, convex epidermal cells and wax crystals can reduce the contact area between water and the leaf surface (Kardel et al., 2012) and consequently, the adsorption the $\mathrm{Na}^{+}$aerosol.

307 The Tilia and $P$. xhispanica leaves, together with those of $O$. europaea, captured the highest number of talcum particles, especially those $<10 \mu \mathrm{m}$, whereas those with a diameter $>10 \mu \mathrm{m}$ were mainly accumulated by oak leaves. After the wash-off treatment $P$. $\times$ hispanica retained almost $90 \%$ of total particles, while O. europaea retained just $13 \%$ (dropping to only $5 \%$ in the $<5 \mu \mathrm{m}$ particle size). Small circumference-to-area ratio in olive might be a reason for the low capacity for particles retention (Freer-Smith et al., 2005). Holm oak leaves retained about 68\% of total adsorbed particles, including those $<5 \mu \mathrm{m}$. In agreement with the results of earlier studies (Freer-Smith et al., 1997; Lindberg and Lovett, 1992) indicating that the median diameter of particles collected by oak tree species would be around $9 \mu \mathrm{m}$, in our experiment the leaves of $Q$. cerris and $Q$. ilex also retained fewer particles in $<5 \mu \mathrm{m}$ range than the other

317 tree species. Carpenter et al. (2005) reported that Platanus and Tilia leaves can collect a very 318 variable range of particle sizes, and in agreement with another study (Jouraeva et al., 2002) our results indicate that Tilia leaves are particularly efficient in the capture of $<10 \mu \mathrm{m}$ particles. 
The tree species we studied ranked in the order: $P$. $\times$ hispanica $>$ T. cordata $>Q$. ilex $>Q$. cerris $>$ O. europaea for the powder retention and in the order T. cordata $>P . \times$ hispanica $=$ Q. cerris $>Q$. ilex $=$ O. europaea for the $\mathrm{NaCl}$ aerosol capture potential. Differences in ranking

323 are likely due to leaf size differences between species (which affect capture even when size differences are accounted for, at a 'unit' level at which we expressed our capture capacities due to a change in turbulences, Beckett et al., 2000) and features including a smooth or wrinkled surface, the presence of micro-roughness, hairs, veins or trichomes (e.g. Beckett et al. 2000; Liu et al., 2012; Speak et al., 2012) and how they would affect the interception of $\left(\mathrm{Na}^{+}\right)$aerosols vs powder. Thoennessen (2002) for instance, investigated the distribution of pollutants on leaves along a street with high traffic volume and distinguished between plants with very rough surfaces and higher pollutant deposition and those (self-cleaners) with smooth surfaces which reduce the particles deposition and favour their removal by precipitation and wind. Among leaf types in this study the relatively smaller leaf size, the sclerophylly (i.e. the reduced wettability) and the smoother surface are probably the main factors affecting the much lower retention of $\mathrm{Na}^{+}$and powder particles on olive and oaks. In all tree species exposed to high-medium traffic intensities over a 3-week period at the street level, there was a statistically significant increase of average leaf $\mathrm{Cu}, \mathrm{Zn}$ and $\mathrm{Pb}$ concentrations (Table 4). While there was no atmospheric precipitation and consequently wash-off of adsorbed particles during the exposure period, the results corroborated the lower capability of $O$. europaea and $Q$. cerris leaves to adsorb airborne particles. In our laboratory experiments $Q$. cerris leaves accumulated the minimum number of total particles; in the field it generally showed lowest particles concentration increase. Both our talcum powder experiment and other studies (Freer-Smith et al., 1997; Tomašević et al. 2008) showed that some oak species mainly capture larger particles.

344 Differences in particulate trapping efficiency have been widely studied in a number of tree species (e.g. Beckett et al. 2000; Freer-Smith et al., 2005; Dzierzanowski et al., 2011). Additional species considered in this study, showed a higher $\mathrm{Na}^{+}$, talcum powder, $\mathrm{Pb}$ and $\mathrm{Cu}$ capture efficiency in London plane and lime tree leaves. However, after the powdering the $Q$. ilex leaves showed a capacity to retain a larger proportion of fine adsorbed particles, compared with London plane and lime. Additionally, holm oak has a significant practical advantage in being an evergreen species with high Leaf Area Index (i.e. a foliar density which should enhance air turbulence around leaves and the PM deposition; Sgrigna et al. 2015). Also, holm oak is well adapted to growing and functioning under the conditions of water deficit, regularly 
experienced in the Mediterranean region (Bussotti et al., 2002), which seems to give advantage to this species over the others as an interceptor of airborne particles in urban areas.

\section{CONCLUSIONS}

Comparisons of the leaf-level capture of aerosol and particles among five species of broadleaf trees which are common in many Mediterranean urban environments showed that $P$. $\times$ hispanica and $T$. cordata leaves intercepted and retained $\mathrm{NaCl}$ aerosol and talcum particles more efficiently than $O$. europea, $Q$. cerris, and $Q$. ilex leaves. In agreement with the results of previous surveys with other tree species, the leaf behaviour seems a species-specific process depending above all on leaf surface morphology and wettability. In general, $Q$. cerris and especially $O$. europea leaves showed the weakest performances, while after the wash-off, $Q$. ilex leaves retained high proportion of fine intercepted particles. Thus, although London plane and lime tree leaves generally fared the best and these species should be considered to decrease the impact of airborne particles in urban environments, due to its evergreen nature, foliage distribution and density which is maintained in all seasons, the holm oak probably, has a greater potential for a year-round air pollutant sequestration in Mediterranean urban environments.

Acknowledgements

We are grateful to the Environmental Department of the University of Siena for providing $\mathrm{PhD}$ studentship funding and the 'Erasmus' funding programme for financially supporting a research visit to the University of Reading for Federica Fantozzi. We are grateful to Matthew Richardson and Andy Conisbee at the University of Reading for help in constructing the wind tunnel.

\section{REFERENCES}

ARPAT, 2011. Rapporto sulla qualità dell'aria della Provincia di Siena. Stazioni locali aggiuntive alla rete regionale. Dipartimento ARPAT di Siena, 1-64. inflammatory response in human airway epithelium. Activation of transcription factors. Cell Biology and Toxicology 15, 375-380. 
Beckett K., Freer-Smith P.H., Taylor G., 2000. Particulate pollution capture by urban trees: effect of species and windspeed. Global Change Biology 6, 995-1003.

Bussotti F., Bettini D., Grossoni P., Mansuino S., Nibbi R., Soda C., Tani C., 2002. Structural and functional traits of Quercus ilex in response to water availability. Environmental and Experimental Botany 47, 11-23.

Buhaug, H., Urdal H., 2013. An Urbanization Bomb? Population Growth and Social Disorder in Cities. Global Environmental Change 23, 1-10.

Carpenter R.J., Hill R.S., Jordan G.J., 2005. Leaf cuticular morphology links Platanaceae and Proteaceae. International Journal of Plant Science 166, 843-855.

Davis D., McClenahen R.J., Hutnik R., 2001, Use of epiphytic moss to biomonitor pollutant levels in southwestern Pennsylvania. Northeastern Naturalist 8, 379-392.

Dzierźanowski K., Popek R, Gawronska H., Sæbø A. and Gawronski S.W., 2011. Deposition of particulate matter of different size fractions on leaf surfaces and in waxes of urban forest species. International Journal of Phytoremediation 13, 1037-1046.

EEA 2014 . European Environment Agency, Air quality in Europe - 2014. Publication Office of the European Union, Report $N^{\circ} 5 / 2014$, Luxembourg.

Escobedo F., Nowak D., 2009. Spatial heterogeneity and air pollution removal by an urban forest. Landscape and Urban Planning 90, 102-110.

Espinosa A.J., Fernandez M., Rodriguez T., Barragan de la Rosa F., Jimenez Sanchez J.C., 2002. A chemical speciation of trace metals for fine urban particles. Atmospheric Environment 36, 773-780.

Fantozzi F., Monaci F., Blanusa T., Bargagli R., 2013. Holm oak (Quercus ilex L.) canopy as interceptor of airborne trace elements and their accumulation in the litter and topsoil. Environmental Pollution 183, 89-95.

Fowler D., Skiba U., Nemitz E., Choubedar F., Brandford D., Donovan R., Rowland P., 2004. Measuring aerosol and heavy metal deposition on urban woodland and grass using inventories of ${ }^{210} \mathrm{~Pb}$ and metal concentrations in soil. Water Air and Soil Pollution: Focus 4,483-499.

Freer-Smith P.H., Holloway S., Goodman A., 1997. The uptake of particulates by an urban woodland: Site description and particulate composition. Environmental Pollution. $95(1), 27-35$. 
Freer-Smith P.H., El-Khatib A., Taylor G., 2004. Capture of particulate pollution by trees: a comparison of species typical of semi-arid areas (Ficus nitida and Eucalyptus globulus) with European and North American species. Water, Air, and Soil Pollution 155, 173-187.

Freer-Smith, P.H., Beckett, K.P., Taylor, G., 2005. Deposition velocities to Sorbus aria, Acer campestre, Populus deltoids trichocarpa 'Beaupre', Pinus nigra and Cupresso cyparisleylandii for coarse, fine and ultra-fine particles in the urban environment. Environmental Pollution 133, 157-167.

Gratani L., Crescente M.F., Varone L., 2008. Long-term monitoring of metal pollution by urban trees. Atmospheric Environment 42, 8273-8277.

Hak C., Larssen S., Randall S., Guettriero C., Denby B., Horalek J., 2009. Traffic and Air Quality. The contribution of traffic to urban air quality in European cities. ETC/ACC Technical paper 19/2010.

HEI, 2010. Traffic related air pollution: A critical review of the literature on emissions, exposure, and health effects. Health Effects Institute, Boston, MA, Special Report 17.

Hofman, J., Bartholomeus, H., Calders, K., Van Wittenberghe, S., Wuyts, K., Samson, R., 2014. On the relation between tree crown morphology and particulate matter deposition on urban tree leaves: A ground-based LiDAR approach. Atmospheric Environment 99, 130-139.

Hölscher D., 2003. Leaf traits and photosynthetic parameters of saplings and adult trees of coexisting species in a temperate broad-leaved forest. Basic and Applied Ecology. 5, 163-172.

Jouraeva A., Johnson D.L., Hassett P.J., Nowak D., 2002. Differences in accumulation of PAHs and metals on the leaves of Tilia euchlora and Pyrus calleryana. Environmental Pollution. 120, 331-338.

Kardel F., Wuyts K., Babanezhad M., Wuytack T., Adriaenssens S., Samson R., 2012. Tree leaf wettability as passive bio-indicator of urban habitat quality. Environmental and Experimental Botany. 75, 277-285.

Kumar P., Pirjola L., Ketzel M., Harrison R.M., 2013. Nanoparticle emissions from 11 nonvehicle exhaust sources - A review. Atmospheric Environment 67, 252-277.

Laćan I., McBride J.R., 2008. Pest Vulnerability Matrix (PVM): A graphic model for assessing the interaction between tree species diversity and urban forest susceptibility to insects and diseases. Urban Forestry \& Urban Greening 7, 291-300. 
Lindberg S.E., Lovett G.M., 1992. Deposition and forest canopy interactions of airborne sulfur: results from the integrated forest study. Atmospheric Environment 26A, 14771492.

Lindgren A., 1996, Asphalt wear and pollution transport. Science of the Total Environment 26, 1477-1492.

Litschke T., Kuttler W, 2008. On the reduction of urban particle concentration by vegetation a review. Meteorologische Zeitschrift 17, 229-240.

Liu S., Russell L.M., Sueper D.T., Onasch T.B., 2012. Organic particle types by single-particle measurements using a time-of-flight aerosol mass spectrometer coupled with a light scattering module, Atmospheric Measurement Techniques, 5, 3047-3077.

Maher B.A., Ahmed I. A. M., Davison B., Karloukovski V., Clarke R., 2013. Impact of roadside tree lines on indoor concentrations of traffic-derived particulate matter. Environmental Science \& Technology 47, 13737-13744.

Marchi S., Tognetti R., Minnocci A., Borghi M., Sebastiani L., 2008. Variation in mesophyll anatomy and photosynthetic capacity during leaf development in a deciduous mesophyte fruit tree (Prunus persica) and an evergreen sclerophyllous Mediterranean shrub (Olea europaea). Trees 22, 559-571.

McPherson E.G., Nowak D. J., Rowntree R.E., 1994. Chicago's Urban Forest Ecosystem: Results of the Chicago Urban Forest Ecosystem Project. USDA general Technical Report NE-186.

Monaci F., Moni F., Lanciotti E., Grechi D., Bargagli R., 2000. Biomonitoring of airborne metals in urban environments: New tracers of vehicle emission, in place of lead. Environmental Pollution 107, 321-327.

NEGTAP, 2001. UK National Expert Group on Transboundary Air Pollution. Defra, London.

Neinhuis C., Barthlott W., 1998. Seasonal changes of leaf surface contamination in beech, oak, and ginkgo in relation to leaf micromorphology and wettability. New Phytologist $138,91-98$.

Nowak, D.J., Crane, D.E., Stevens, J.C., 2006. Air pollution removal by urban trees and shrubs in the United States. Urban Forestry \& Urban Greening 4, 115-123.

Pope C.A., Dockery D.W., 2006. Health effects of fine particulate air pollution: Lines that connect. Journal of the Air and Waste Management Association 56, 709-742.

Pugh A.M., MacKenzie A.R., Whyatt J.D., Hewitt C.N., 2012. Effectiveness of green architecture for improvement of air quality in urban street canyons. Environmental Science \& Technology 46, 7692-7699. 
Quero J. L., Villar R., Marañón T., Zamora R., 2006, Interactions of drought and shade effects on seedlings of four Quercus species: physiological and structural leaf responses. New Phytologist. 170, 819-834.

Räsänen A., Rusanen A., Kuitunen M., Lensu A., 2013. What makes segmentation good? A case study in boreal forest habitat mapping. International Journal of Remote Sensing 34, 8603-8627.

Sæbø, A., Popek, R., Nawrot, B., Hanslin, H. M., Gawronska, H., Gawronski, S. W., 2012. Plant species differences in particulate matter accumulation on leaf surfaces. Science of The Total Environment 427-428, 347-354.

Sgrigna, G., Sæbø, A., Gawronski, S., Popek, R., and Calfapietra, C., 2015. Particulate Matter deposition on Quercus ilex leaves in an industrial city of central Italy. Environmental Pollution 197, 187-194.

Speak A., Rothwell J., Lindley S., Smith C., 2012.Urban particulate pollution reduction by four species of green roof vegetation in a UK city. Atmospheric Environment 61, 283293.

Tallis, M., Taylor, G., Sinnett, D., Freer-Smith, P., 2011. Estimating the removal of atmospheric particulate pollution by the urban tree canopy of London, under current and future environments. Landscape and Urban Planning 103, 129-138.

Tomašević M., Vukmirović Z., Rajšić S., Tasić M., Stevanović B., 2008. Contribution to biomonitoring of some trace metals by deciduous tree leaves in urban areas. Environmental Monitoring and Assessment 137, 393-401.

Thoennessen M (2002) Elementdynamik in fassadenbegrünendem Wilden Wein, Kölner Geograph. Arbeiten Heft 78, 1-110.

Ugolini F., Tognetti R., Raschi A., Bacci L., 2013. Quercus ilex L. as bioaccumulator for heavy metals in urban areas: effectiveness of leaf washing with distilled water and considerations on the trees distance from traffic. Urban Forestry \& Urban Greening $12,576-584$.

Wang X., 2006. Management of agricultural nonpoint source pollution in China: current status and challenges. Water Science and Technology 53, 1-9.

Weber, F., Kowarik, I., Säumel, I., 2014. Herbaceous plants as filters: Immobilization of particulates along urban street corridors. Environmental Pollution 186, 234-240.

WHO 2014. Air Quality and Health. Word Heath Organization, Fact Sheet $n^{\circ} 313$ - Updated March 2014 (http://www.who.int/mediacentre/factsheets/fs313/en/) 

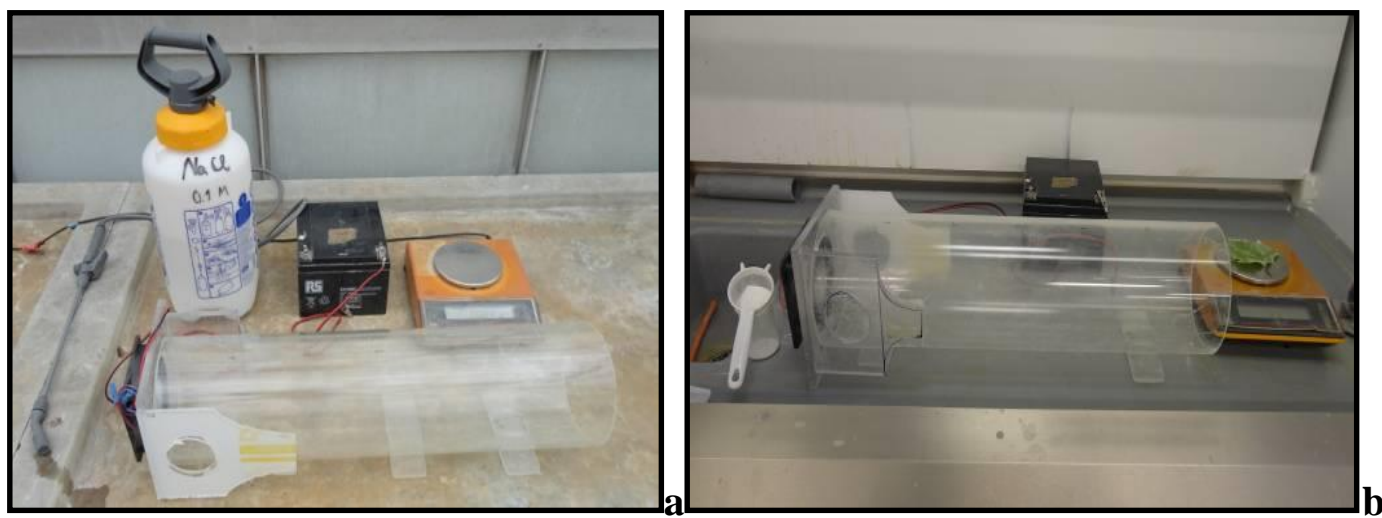

Figure 1: Wind-water tunnel (open-circuit type) used in the experiments: a. with the spray dispenser,

523 b. with the talcum powder.

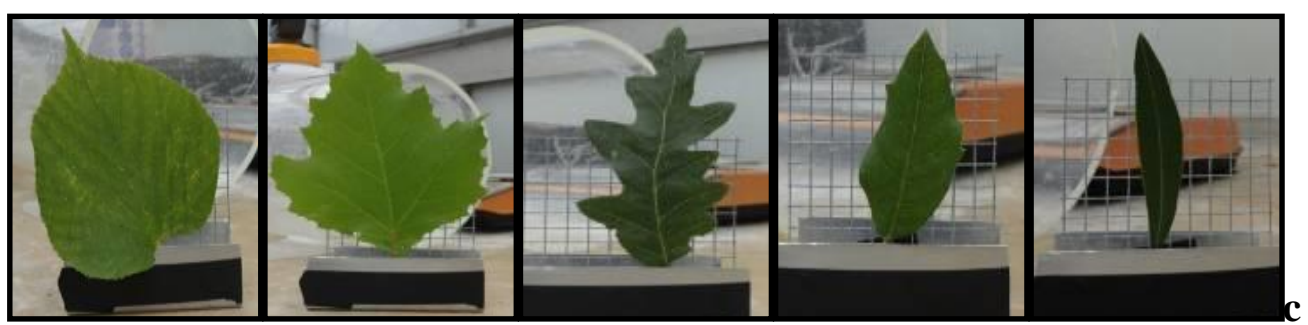

Figure 2: Leaves of the five tree species inserted in an iron support, from left to right: T. cordata, $P$. ×hispanica, Q. cerris, Q. ilex, O. europaea.

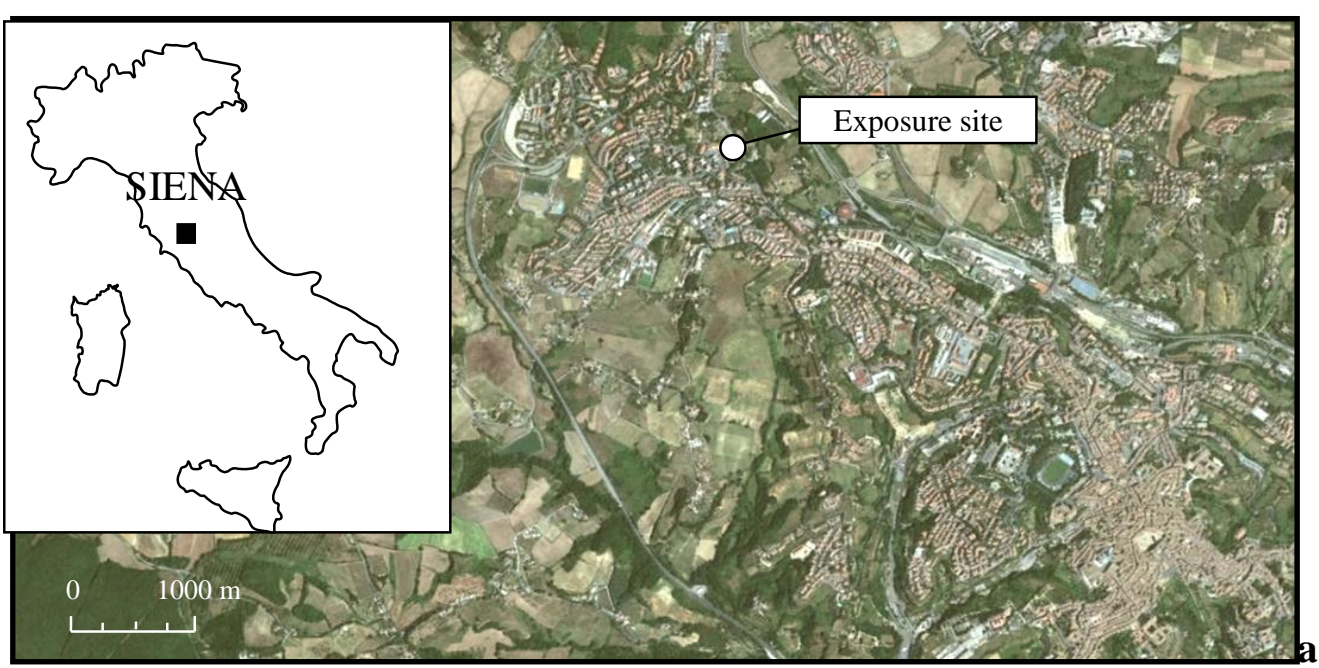

Figure 3: Location of the urban street where three branches with five leaves each, for each studied species, 533 were exposed on a wall ( $1 \mathrm{~m}$ away from the street, $2 \mathrm{~m}$ above the ground). 
Table 1: Tree species used in the experiment and their leaf properties.

537

\begin{tabular}{lcccc}
\hline Tree species & & \multicolumn{3}{c}{ Leaf properties } \\
\cline { 2 - 5 } & fall/retention & Hairs & waxes & size $\left(\mathrm{cm}^{2}\right)^{*}$ \\
\hline $\begin{array}{l}\text { Platanus } \times \text { hispanica } \\
\text { (London plane) }\end{array}$ & Deciduous & Yes & Scarce & $77.1 \pm 4.8$ \\
$\begin{array}{l}\text { Tilia cordata } \\
\text { (Lime tree) }\end{array}$ & Deciduous & Sparse & Scarce & $42.5 \pm 4.3$ \\
$\begin{array}{l}\text { Quercus ilex } \\
\text { (Holm oak) }\end{array}$ & Evergreen & Sparse & Pronounced & $14.3 \pm 0.9$ \\
$\begin{array}{l}\text { Quercus cerris } \\
\text { (Turkey oak) } \\
\begin{array}{l}\text { Olea europaea } \\
\text { (Olive tree) }\end{array}\end{array}$ & Deciduous & No & Pronounced & $24.1 \pm 2.1$ \\
\hline
\end{tabular}

*Average leaf size of experimental leaves

\begin{tabular}{|c|c|c|c|}
\hline Tree species & $\begin{array}{c}\text { Leaf } \mathrm{Na} \\
\text { concentration } \\
\left(\mathrm{mg} \mathrm{g}^{-1}\right)\end{array}$ & $\begin{array}{c}\text { Leaf } \mathrm{Na} \\
\text { concentration } \\
\text { 'Cp' } \\
\left(\mathrm{mg} \mathrm{cm}{ }^{-2}\right)\end{array}$ & $\begin{array}{c}\text { Runoff water } \\
\mathrm{Na} \\
\text { concentration } \\
\left(\mathrm{mg} \mathrm{l}^{-1} \mathrm{~cm}^{-2}\right)\end{array}$ \\
\hline P. $\times$ hispanica & $1.34 \pm 0.04 \mathrm{~b}$ & $\frac{0.008 \pm 0.0003}{b}$ & $0.30 \pm 0.02 \mathrm{~b}$ \\
\hline T. cordata & $1.97 \pm 0.14 \mathrm{a}$ & $\frac{0.015 \pm 0.0013}{\mathrm{a}}$ & $0.20 \pm 0.02 \mathrm{a}$ \\
\hline Q. cerris & $0.55 \pm 0.03 \mathrm{c}$ & $\frac{0.009 \pm 0.0007}{\mathrm{~b}}$ & $0.53 \pm 0.01 \mathrm{c}$ \\
\hline Q. ilex & $0.53 \pm 0.07 \mathrm{c}$ & $\frac{0.003 \pm 0.0004}{\mathrm{c}}$ & $0.55 \pm 0.03 \mathrm{c}$ \\
\hline O. europaea & $0.36 \pm 0.01 \mathrm{c}$ & $\frac{0.002 \pm 0.0002}{\mathrm{c}}$ & $1.87 \pm 0.09 \mathrm{~d}$ \\
\hline $\operatorname{LSD}($ d.f. $=35)$ & 0.2511 & 0.0024 & 0.098 \\
\hline
\end{tabular}

Table 2. Leaf $\mathrm{Na}^{+}$concentrations after aerosol application (expressed in $\mathrm{mg} \mathrm{g}^{-1}$ and $\mathrm{mg} \mathrm{cm}^{-2}$ ) and $\mathrm{Na}^{+}$concentrations in the runoff $\left(\mathrm{mg} \mathrm{l}^{-1} \mathrm{~cm}^{-2}\right)$ after rinsing with r.o. water. Data are mean of 6-9 replicates per plant species, presented with associated LSD and d.f. Different letters next to the means in each column indicate that means are significantly different. 
549 Table 3: Powder particle retention (mean number of particles $\mathrm{mm}^{-2} \pm$ SEM as well as the associated LSD for each particle class size) and particle 550 size (class: $<5,5-10$ and $>10 \mu \mathrm{m})$ in tree leaves $(\mathrm{n}=20)$ after powdering and wash-off steps for the five studied species. Different letters next to 551 the means in each column indicate that means are significantly different.

\begin{tabular}{|c|c|c|c|c|c|c|c|c|c|}
\hline \multicolumn{5}{|c|}{ after powdering (num/mm²) } & \multicolumn{5}{|c|}{ after wash-off (num/mm²) } \\
\hline & $<5 \mu \mathrm{m}$ & $5-10 \mu \mathrm{m}$ & $>10 \mu \mathrm{m}$ & tot & $<5 \mu \mathrm{m}$ & $5-10 \mu \mathrm{m}$ & $>10 \mu \mathrm{m}$ & tot & $\%$ change \\
\hline P.hispanica & $2688 \pm 65 b$ & $3779 \pm 80 b$ & $1673 \pm 49 \mathrm{c}$ & $8140 \pm 65 b$ & $1121 \pm 46 \mathrm{c}$ & $3613 \pm 66$ a & $2757 \pm 96$ a & $7491 \pm 69 \mathrm{a}$ & $93.6 \pm 2.0 \mathrm{a}$ \\
\hline T.cordata & $3007 \pm 556 \mathrm{a}$ & $5741 \pm 600 \mathrm{a}$ & $787 \pm 242 \mathrm{e}$ & $9535 \pm 466 \mathrm{a}$ & $378 \pm 189 \mathrm{~b}$ & $3461 \pm 648 b$ & $1052 \pm 245 \mathrm{c}$ & $4891 \pm 361 b$ & $52.2 \pm 2.3 \mathrm{c}$ \\
\hline Q.cerris & $378 \pm 172 \mathrm{~d}$ & $2014 \pm 217 \mathrm{c}$ & $2537 \pm 273 \mathrm{a}$ & $4928 \pm 220 \mathrm{~d}$ & $159 \pm 141 \mathrm{a}$ & $742 \pm 153 \mathrm{~d}$ & $856 \pm 111 \mathrm{~d}$ & $1757 \pm 135 \mathrm{c}$ & $35.8 \pm 1.0 \mathrm{~d}$ \\
\hline Q.ilex & $795 \pm 234 \mathrm{c}$ & $3891 \pm 284 \mathrm{~b}$ & $2243 \pm 262 b$ & $6929 \pm 260 \mathrm{c}$ & $482 \pm 198 b$ & $2584 \pm 223 \mathrm{c}$ & $1675 \pm 176 b$ & $4741 \pm 199 b$ & $68.6 \pm 1.1 \mathrm{~b}$ \\
\hline O.europaea & $3007 \pm 471 \mathrm{a}$ & $5483 \pm 595 \mathrm{a}$ & $1287 \pm 309 \mathrm{~d}$ & $9777 \pm 458 \mathrm{a}$ & $151 \pm 72 \mathrm{a}$ & $507 \pm 103 \mathrm{e}$ & $575 \pm 105 \mathrm{e}$ & $1233 \pm 93 \mathrm{~d}$ & $12.4 \pm 0.64 \mathrm{e}$ \\
\hline$L S D(d . f .=99)$ & 245 & 275.8 & 170.2 & 373.1 & 118.4 & 229.3 & 165.4 & 319.6 & 4.33 \\
\hline
\end{tabular}


Table 4: Average concentration $\left(\mu \mathrm{g} \mathrm{g}^{-1}\right)$ with the associated least significant difference $(\mathrm{LSD}$, d.f. $=14)$ of heavy metals in leaves $(\mathrm{n}=3)$ before $\left(\mathrm{t}_{1}\right)$ and after $\left(\mathrm{t}_{2}\right)$ the roadside exposure and percentage of increase with respect to $t_{1}$.

\begin{tabular}{|c|c|c|c|c|c|c|c|c|c|}
\hline \multirow[b]{2}{*}{ Species } & \multicolumn{3}{|c|}{$\mathrm{Pb}\left(\mu \mathrm{g} \mathrm{g}^{-1}\right)$} & \multicolumn{3}{|c|}{$\mathrm{Cu}\left(\mu \mathrm{g} \mathrm{g}^{-1}\right)$} & \multicolumn{3}{|c|}{$\mathrm{Zn}\left(\mu \mathrm{g} \mathrm{g}^{-1}\right)$} \\
\hline & $t_{1}$ & $t_{2}$ & $\begin{array}{c}\% \\
\text { increase }\end{array}$ & $\mathrm{t}_{1}$ & $\mathrm{t}_{2}$ & $\begin{array}{c}\% \\
\text { increase }\end{array}$ & $\mathrm{t}_{1}$ & $t_{2}$ & $\begin{array}{c}\% \\
\text { increase }\end{array}$ \\
\hline $\begin{array}{l}P . \\
\times \text { hispanica }\end{array}$ & 0.13 & 0.18 & 27.9 & 7.00 & 9.54 & 26.6 & 12.46 & 14.7 & 15.40 \\
\hline T. cordata & 0.14 & 0.18 & 22.3 & 10.96 & 13.78 & 20.4 & 12.83 & 14.28 & 10.15 \\
\hline Q. cerris & 0.23 & 0.3 & 21.8 & 9.47 & 11.45 & 17.4 & 10.85 & 12.3 & 13.30 \\
\hline Q. ilex & 0.33 & 0.37 & 12.2 & 10.5 & 12.59 & 16.5 & 15.29 & 16.84 & 9.20 \\
\hline $\begin{array}{l}O . \\
\text { europaea }\end{array}$ & 0.38 & 0.39 & 5.8 & 7.42 & 8.55 & 12.9 & 13.02 & 14.75 & 11.73 \\
\hline LSD & 0.049 & 0.058 & & 0.655 & 0.656 & & 0.627 & 0.87 & \\
\hline
\end{tabular}

